\title{
Historical Diaglossia and the Selection of Multiple Norms: Mij and Mijn as 1st Person Singular Object Pronouns in 17th- and 18th-Century Dutch
}

\author{
Gijsbert Rutten
}

Leiden University

\begin{abstract}
This paper argues that the Dutch sociolinguistic situation in the 17 th and 18th centuries should be analyzed as diaglossic, that is, involving a wide spectrum of variation in between localized spoken dialects and the supposed written standard. In fact, multiple instances of norm selection for writing render this diaglossic situation even more complex. The paper shows that multiple norm selection even occurred in cases when a strict and simple norm was selected early on, that is, in the late 16thearly 17th century. The case study is based on the Letters as Loot Corpus comprising private letters from the $1660 \mathrm{~s}-1670 \mathrm{~s}$ and the 1770s-1780s and focuses on the object form of the 1st person singular personal pronoun, namely, mij or mijn. Despite the early selection of mij, some language users in the late 17th and 18th century adopted mijn in writing. The analysis shows a normative split in written Dutch of the time, with most language users either converging to or diverging from the supposed standard form mij. ${ }^{*}$
\end{abstract}

Keywords: Dutch, historical sociolinguistics, diaglossia, object pronouns, standardization

\section{Introduction.}

The Dutch language in the 17th and 18th centuries is often described in terms of selection and codification as part of the ongoing standardization

\footnotetext{
* I wish to thank the reviewers of the Journal of Germanic Linguistics for their useful comments on an earlier draft. Thanks also to Marijke van der Wal (Leiden), Tanja Simons (Leiden), and Giulia Mazzola (Louvain), who were convinced mij/mijn constituted an interesting variable well before I was.

(C) Society for Germanic Linguistics. This is an Open Access article, distributed under the terms of the Creative Commons Attribution license (http://creativecommons.org/licenses/by/4.0/), which permits unrestricted reuse, distribution, and reproduction in any medium, provided the original work is properly cited.
} 
of the written language (van der Wal 1995, van den Toorn et al. 1997, van der Sijs 2004, Janssens \& Marynissen 2005). Recent studies have shown that the sociolinguistic situation was more complex in that written sources of the period and in particular ego-documents, such as private letters, display considerable regional, social, and individual variation (Howell 2006, Goss \& Howell 2006, Nobels 2013, Simons 2013, Rutten \& van der Wal 2014, Krogull 2018). Instead of focusing on the supposed standard, the linguistic situation in the 17th and 18th centuries can therefore more aptly be described in terms of DIAGLOSSIA, indicating a wide spectrum of variation in between localized spoken dialects on the one hand and the supposed standard found in published texts and metalinguistic discourse on the other (Rutten 2016a).

This paper shows that the situation was even more complex: Whereas some language users resolved the variation in the diaglossic spectrum by adopting the variants selected for the standard, other language users selected, and kept selecting, other forms, thus diverging from the supposed standard. This latter scenario even occurred in cases in which a strict and simple norm was selected early on. The example used here is the object form of the 1st person singular personal pronoun. While mij 'me' had been selected for the standard in the late 16th and early 17 th century, the form mijn 'me' was still in use in the late 17th century and remained in use in the 18th century, including among individuals who participated strongly in the written culture. Their preference for mijn signals a secondary process of selection, whereby some language users selected the variant that had long been deselected. The diaglossic situation is thus complicated by multiple and diverging processes of selection.

The structure of the paper is as follows. Section 2 discusses historical diaglossia and the standardization of Dutch. Section 3 introduces the mij/mijn variable, and section 4 the corpus used for the case study. The results are presented in section 5 and discussed in section 6 .

\section{Historical Diaglossia and the Standardization of Dutch.}

2.1. Historical Diaglossia and the Selection of Norms.

Auer (2005:22) describes diaglossia as a situation with intermediate variants located between the standard and base dialects as a result of modern developments such as destandardization, dialect loss, and endoglossic standardization in pluricentric languages (see Grondelaers \& 
van Hout 2011). Auer $(2005,2011)$, writing about European languages in general and Grondelaers \& van Hout (2011), analyzing the Dutch case, consider diaglossia to be a 19th- or 20th-century development, which follows a previous state of dialect-standard diglossia. Various authors have applied the concept of diaglossia to historical-sociolinguistic situations, arguing that in Late and post-Medieval Europe, sociolinguistic constellations in many language areas were also much more variable than a rigid description in terms of dialect-standard diglossia can account for. Dossena (2012:26-27) notes that the study of historical correspondence makes it necessary to adopt a diaglossic conception of writing, since historical letter writers go beyond the diglossic idea of dialect versus standard, displaying a much wider range of styles and codes. Nevalainen (2012:129-132) argues that various endoglossic spelling norms arose in Late Medieval and Early Modern England, characterizing the situation as diaglossic, before focusing set in on a larger scale and English spelling was standardized. Elspaß (2014a:51) argues that the traditional diglossic perspective with spoken local dialects on the one hand, and a uniform written standard on the other, cannot be maintained with respect to 19thcentury German in view of the wide-ranging variation found in written sources, such as private letters. Reviewing evidence from historical Dutch, English, and German, Rutten (2016a) contends that these languages were characterized by a state of diaglossia in the Early and Late Modern period.

The diaglossic situation recognizable in the history of many European languages from the Late Medieval and Early Modern period onward refers to the written language. It is assumed that people spoke their local dialects, and at the same time norms for writing can be found indirectly in published texts and directly in metalinguistic discourse. The issue at stake is that historical-sociolinguistic evidence based on written sources shows that wide-ranging variation existed in writing, in addition to these two poles of local, spoken dialects on the one hand, and published texts and metalanguage on the other. The language use found in these written sources sometimes converges toward norms that are different from the supposed standard norms found in published texts and in metalinguistic publications; they may be referred to as "norms of usage" (Elspaß 2014b). For example, the standard norm for the German preposition wegen holds that it should be combined with the genitive, whereas historical usage data suggest that the dative and the accusative 
were the actual norms adopted by many language users in their writings (Elspaß 2014b:315-316).

Furthermore, the variability found in written sources can be extended to metalinguistic texts. Despite the fact that particularly the Early Modern period of languages such as Dutch, German, English, and French is often described in terms of selection and codification in the sense of Haugen (1966), the printers, schoolteachers, grammarians, and so on involved in these processes were not always in harmony with each other (for example, Poplack et al. 2015). In fact, the different opinions found in historical metalinguistic discourse does not warrant an analysis in terms of a unilinear, teleological conception of standardization (Elspaß 2014b:308-309) but requires a variation-oriented approach in terms of multiple codifications (Rutten 2016a:19-22).

Ongoing selection and deselection at the micro-level of individual variables (van der Wal 2007, Pickl 2020) usually involved assigning social meaning to particular variants or trying to figure out what social meanings were active in contemporary language communities (Lodge 2013, Ayres-Bennett 2014). Deselection, or nonselection, often cooccurred with or led to the stigmatization of existing variants such as wegen with dative, auxiliary tun and polynegation in 18th-century German (Langer 2014). These can be considered old norms of usage that were not selected for the standard.

The present paper also analyzes such existing norms of usage, namely, the use of the 1st person singular personal pronoun mijn in object position in 17th- and 18th-century Dutch. The form mij, without the final nasal, had been selected for the standard early on, so that mijn was deselected. Social meaning had been attached to these forms, and as I show in section 5, some social groups began to behave in line with this development. Nevertheless, other groups still opted for mijn, and moreover, seemed to adopt mijn in a secondary process of selection. I aim to show that the variable situation of language use was not only resolved by gradual convergence to the supposed standard, but simultaneously, among some language users, by the establishment of another norm, thus adding significantly to the complexity of the sociolinguistic constellation. 


\subsection{Diaglossia and a Dutch Standard.}

Traditional histories of Dutch contend that the second half of the 16th and the first half of the 17 th century constitute a crucial stage in the selection and codification processes resulting in a Dutch standard language by 1650 (van der Wal 1995, van den Toorn et al. 1997, van der Sijs 2004, Janssens \& Marynissen 2005). Morphophonological and morphosyntactic phenomena have traditionally played an important role in this context. Examples include apocope of final schwa (as in ic leve $>$ ik leef 'I live', hase > haas 'hare', bose > boos 'angry'), the rise of palatalized diminutive suffixes (for example, -je or -tje replacing Middle Dutch forms such as -eken and -ke), and of a specialized reflexive pronoun in the 3 rd person (zich), the loss of the personal pronoun $d u$ in the 2nd person singular (replaced by originally plural form gij), and the shift from bipartite to single negation (van der Wal 1995:68, 75-76, van den Toorn et al. 1997:286, 302-303, van der Sijs 2004:427, 460-462, 482, 535-536).

The interpretation in terms of selection and codification has been criticized from various perspectives. Howell (2006) and Goss \& Howell (2006), for example, argue that various changes in 16th- and 17thcentury Dutch are the result of koineization in an extreme contact setting with large numbers of migrants. Nobels (2013) and Rutten \& van der Wal (2014) demonstrate that 17th-century Dutch as found in private letters by a cross-section of the population displays wide variability with respect to some of the phenomena mentioned above. For example, regional writing practices seem to lie behind the distribution of diminutive suffixes and negation, even in the second half of the 17th century, at a time when zich constitutes no more than $21 \%$ of all 3 rd person singular reflexive pronouns (Nobels 2013). Based on these results, Rutten (2016b) argues that one should avoid talking about the 17 th-century Dutch in terms of standardization.

Rutten (2016c) discusses the case of negation in the context of diaglossia, standardization, and individual variation. Single negation was supposedly selected for the standard in the first half of the 17th century, but usage data from private letters from the second half of the century still show 35\% bipartite negation, which raises the question to what extent the supposedly selected form, namely single negation, constituted a norm for letter writers. The question of a single norm becomes even more problematic in view of the data for individuals. An analysis of the 
results of 84 individuals who produced at least 5 negation tokens shows that only 26 of them used negation categorically: 21 used single negation all the time, and 5 used bipartite negation all the time. This means that 58 letter writers used both single and bipartite negation, and in this situation of wide-ranging variation, almost any proportion seemed possible: from less than $20 \%$ single negation to more than $80 \%$, and almost everything in between. This picture of extreme variation, primarily conditioned by regional and internal factors, strongly suggests the absence of a clear norm for written communication, be it single or bipartite negation.

Well-known literary authors such as P.C. Hooft (1581-1647) and J. van den Vondel (1587-1679) consciously switched to single negation around 1640, and the issue was also commented upon in metalinguistic discourse so that the change from bipartite to single negation has become one of the typical examples in histories of the standardization of Dutch (van der Sijs 2004:534-537, van der Wal \& van Bree 2008:217-218). The evidence presented by Nobels (2013) and Rutten (2016c), however, suggests that there was no clear norm for negation in the wider language community. The sociolinguistic situation in the Netherlands in the 17th century should instead be analyzed as diaglossic (Rutten 2016c). The real standardization of Dutch occurred only around 1800, when the standard language ideology had come into being and strongly influenced social and cultural policies at the national level, including language planning and language-in-education planning (Rutten 2019).

Another morphological phenomenon often discussed in the context of norm selection and standardization in the 17th century is the object form of the personal pronoun in the 1st person singular: mij or mijn. The present paper shows that here, too, the situation is more complex than usually thought.

\section{The Mij/Mijn Variable.}

The common Middle Dutch dative and accusative form of the 1st person singular personal pronoun is $m i$ 'me' (Schönfeld 1970:135, Van Loey 1980:33, van Bree 1987:251). In later Middle Dutch and Early Modern Dutch, diphthongization of the vowel in central areas such as Holland and Brabant led to the spellings $m y$ and $m i j$. The present-day standard form is mij ([meI]). In later Middle Dutch, that is, from the 14th and 15th century onward, forms with a nasal consonant in final position occur, 
such as myn and mijn (van Helten 1887:435, van Halteren 1906:13-14, Schönfeld 1970:135, Van Loey 1980:33, van der Horst 2008:588).

The origin of the forms with the nasal is usually found in the possessive pronoun (Schönfeld 1970:135), the uninflected form of which is commonly mijn or myn 'my' in Middle Dutch (Schönfeld 1970:143, Van Loey 1980:41). It is mijn ([meIn]) in present-day standard Dutch. Schönfeld (1970:136) observes that possessive and object forms often coincide in the 2nd and 3rd person, as well as in the 1st person plural. For example, in het is ons boek 'it is our book', the possessive pronoun is identical to the personal pronoun following a preposition, as in het boek is van ons lit. 'the book is of us', that is, 'the book is ours'. He assumes that mijn came to be analogically used in object positions: het is mijn boek 'it is my book' versus het boek is van mij lit. 'the book is of me', that is, 'the book is mine' > het boek is van mijn. According to van Bree (2012:235-239), the "promotion" of the possessive pronoun mijn to object functions of the personal pronoun is part of a more general tendency in Dutch dialects to promote possessive forms to object forms, and possessive and/or object forms to subject forms. The much-debated subject form hun 'they' in present-day standard Dutch is an example of object-to-subject promotion (van Bree 2012). Other analogies have also been suggested in order to explain the rise of mijn in object functions. Van Loey (1980:33) proposes an analogy with the dative and accusative forms of the masculine definite article, which was originally dien in Middle Dutch, but later die emerged as an alternative. Van Helten $(1887: 435,437)$ and Van Loey $(1980: 33)$ observe that the feminine 3rd person singular personal pronoun is haers in the genitive and haer in the dative and accusative, while mijns is the genitive of the 1 st person singular personal pronoun. They therefore suspect the analogy haers : haer=mijns : mijn .

At present, the form with the nasal still exists. It can be found in many dialects along the coast, from West Flanders to Zeeland and southern and northern Holland, with a high concentration in the Zeeland area (Goeman et al. 2008, map 44). The forms are also frequent in inland regions such as Brabant, Utrecht, and Gelderland (Goeman et al. 2008, map 44; van der Sijs 2004:485). The forms with the nasal are usually not considered to be standard Dutch.

The dialectal, or nonstandard status of mijn can also be found in historical Dutch, in which mij was selected for the standard. Although 
mijn is said to have been common in late Middle Dutch and in the 16th century (van Helten 1887:435, van Halteren 1906:13-14, van der Horst 2008:588), its use is more restricted in subsequent periods. Van der Horst (2008:1092) says it is frequent in 17th-century texts from the Holland area, giving, however, predominantly examples from farces; he has no examples from the 18th century. Van Helten (1881:122) claims that mijn is frequent in comedies and farces from the 17th and 18th centuries but records only two examples from the well-known literary author Vondel, one of which occurs in rhyme position, the other in a poem addressed to the common people. In most metalinguistic texts of the 16th and 17th centuries, the issue is not commented upon (van der Wal 2007:91). Only one grammarian, Van Heule, has mijn alongside mij in the first edition of his grammar of 1625 , but not anymore in the revised second edition of 1633 (van Heule 1625:38, 1633:71). The absence of metalinguistic comments does not imply it was a low-awareness feature. On the contrary, it seems to have been so obvious that mij was selected for writing that no further elaboration was deemed necessary. There is one explicit metalinguistic comment revealing the social meanings attached to mij and mijn. When the translators of the state-supported Bible, which would be published in 1637, discussed linguistic issues, they selected $m i j$, adding "nunquam mijn, ut vulgus hic loquitur" [never mijn, as ordinary people say] (van der Wal 2007:91; see van der Wal 1995:34-35).

The early and seemingly undisputed selection of mij resembles the selection process for most other forms in the domain of personal pronouns. The 1st person subject forms $i k$ 'I' and wij 'we', the object form ons 'us', the 3rd person subject and object forms hij 'he', zij 'she', het 'it', zij 'they', hem 'him', and haar 'her' were all selected for the standard in the same period, or even earlier in Middle Dutch writing. Most variation, and hence ongoing selection, occurred in the 2 nd person and in the object forms of the 3rd person plural (van der Sijs 2004:468-481).

The low frequency of mijn in published texts and in metalinguistic discourse from the 17th century onward and its strong condemnation by the translators of the Bible suggest a clear single norm for writing, namely, mij. After a period of variation in the late Middle Ages and in the 16th century, the late 16th and the 17th century thus soon saw the selection of mij for writing and the concomitant deselection of mijn. Previous historical-sociolinguistic research by van der Wal (2007:91-92) has however revealed that in some 18th-century ego-documents mijn still 
frequently occurs. Van der Wal's (2007) study is based on a small number of texts so that a more extensive corpus-based analysis seems appropriate.

\section{Method.}

This study is based on the Letters as Loot Corpus (van der Wal et al. 2015), a historical corpus of Dutch private letters from the 17th and 18th centuries (Rutten \& van der Wal 2014). ${ }^{1}$ These letters were aboard ships that were taken by privateers during the frequent Anglo-Dutch wars in the 17th and 18th centuries, and they were brought to England as part of the legal procedure that followed. Today, they are kept in the National Archives in Kew, London.

The Letters as Loot Corpus was built for the purpose of historicalsociolinguistic analysis, and in particular to bring the so-called perspective from below (Elspaß 2005) into the history of Dutch. Language history from below aims to incorporate data from users into the analysis who were previously underrepresented - for example, by focusing on ego-documents such as private letters written by lessprivileged authors. Furthermore, the apparent social and regional diversity of the letter writers in the archival letter collection was taken into account during corpus compilation. The corpus was thus also built to assess the relevance of the broad categories distinguished in modern sociolinguistics (for example, rank, gender, age, region) for historical Dutch, much in the spirit of Nevalainen \& Raumolin-Brunberg (2003), who applied modern sociolinguistic theory and methods to historical English. The Letters as Loot Corpus thus comprises letters written by individuals of different socioeconomic position and by men as well as women, mostly from the western/northwestern regions of the Dutch language area. The letters were transcribed from digital images of the original manuscripts. More information on the sociohistorical background of the material and on the corpus compilation can be found in Nobels 2013, Simons 2013, and Rutten \& van der Wal 2014. Table 1 summarizes the basic numbers of the sources used for this study.

\footnotetext{
${ }^{1}$ The Letters as Loot Corpus was compiled with the assistance of volunteers of the Leiden-based Wikiscripta Neerlandica transcription project, and lemmatized, tagged and provided with search facilities by the Dutch Language Institute (INT).
} 


\begin{tabular}{l|c|c|c} 
Period & Letters & Writers & Words \\
\hline $1660 \mathrm{~s}-1670 \mathrm{~s}$ & 260 & 202 & 228,000 \\
$1770 \mathrm{~s}-1780 \mathrm{~s}$ & 384 & 292 & 196,500
\end{tabular}

Table 1. Basic numbers of the corpora used.

The corpus covers two periods (the second half of the 17th century and the second half of the 18th) in order to trace language change in real time.

The letters are linked to various regions in the Low Countries, though the large majority were written by people originating from the provinces of Holland and Zeeland in the western part of the present-day Netherlands, where the most important ports were (such as Amsterdam, Rotterdam, Middelburg). The regional analysis (section 5.3) is therefore based on the letters from Holland and Zeeland. These two large historical areas were further distinguished into four regions, namely, Zeeland, South Holland, Amsterdam, and North Holland. The city of Amsterdam lies in the present-day province of North Holland, but it was kept apart for demographic reasons: It was a metropolis in a language area with mostly smaller towns and cities (Rutten \& van der Wal 2014:11-12; see also Nobels 2013:28-34 for more information on the division into four main regions).

Social metadata could be obtained for all 38418 th-century letters and for 219 out of 26017 th-century letters. In view of the supposedly strong indexicality of the form under investigation, social rank is the main focus in the present study. The Letters as Loot Corpus is unique in that it allows for a division into different social layers characteristic of the highly urbanized western parts of the Netherlands in the Early Modern period. The social stratification adopted for the corpus is based on the one commonly used by social historians (Rutten \& van der Wal 2014:10). Four social ranks are distinguished, namely, lower, lower-middle, upper-middle, and upper. Lower comprises wageworkers such as sailors and soldiers (36 letters), lower-middle includes the petty bourgeoisie (for instance, petty shopkeepers, minor officials; 138 letters), upper-middle includes the prosperous middle class (such as large storekeepers, noncommissioned officers; 276 letters), and upper refers to the bourgeoisie (such as wealthy merchants, ship owners, commissioned officers; 153 letters). Importantly, the Letters as Loot Corpus does not comprise any materials related to the highest social rank in contemporary society, namely, the nobility and the 
non-noble ruling classes, which should be considered higher in socioeconomic terms than the upper ranks in the corpus and in this study. The social rank analysis is supplemented with a gender analysis where possible and appropriate, though it should be noted that letters by women (154 in total) are sparse in some cases, such as the lower ranks in the 18th century (only 2 letters), so that a further breakdown of the data is not always useful (see Rutten \& van der Wal 2014:136).

Relevant instances of $m i j$ and mijn were extracted from the corpus by looking for a wide range of spelling options based on the lemmatization of the online version of the Letters as Loot Corpus (for example, mee, meij, mi, my, meijn, min, myn). The historical loss of case endings renders mij and mijn the most frequent forms in the corpus, though inflected instances can also be found. For example, there are 40 tokens of mijne in the 17th-century data, and 5 of myne. Such inflected tokens were left out of the analyses.

Although the literature is quite silent about internal factors, all relevant instances of mij and mijn were tagged for two, namely, grammatical function and phonetic context. The origin of mijn in object position seems to be related to the possessive function (section 3). The grammatical functions distinguished in the present study are direct object (1a), indirect object (1b), prepositional phrase (1c), reflexive (1d), and possessive (1e). The examples are taken from the Letters as Loot Corpus.

(1) a. voorders bidde ick ul hertelick dat gheij mijn niet further beg I you heartily that you me not

wildt ver gheter ijn ul gebet

want forget in your prayer

'Further, I beg you heartily that you will not forget me in your prayer'

(Annetje Elias, 1672)

b. Jck ben verwondert dat ghij lieden

I am surprised that you people

mijn geen schoenen en stuert

me no shoes not send

'I am surprised that you don't send me any shoes'

(Antonis Rijkaart, 1672) 
c. soent mijne kinderen voor mij kiss my children for me 'kiss my children on my behalf'

(Jacobus Almers, 1780)

d. ik vrees dat ik my daar te veel aan besondig I fear that I me that too much on sinn 'I fear that I'm too often guilty of that' (Meymerigje Buyk, 1780)

e. ben swak in mijn hooft am weak in my head '[I] am weak in my head' (Antonia Donkers-van Haaften, 1780)

From the perspective of Early and Late Modern metalinguistic discourse, pronouns in the possessive function should have the forms with the nasal (mijn), whereas pronouns in all other functions should lack the nasal (mij). Insertion of the nasal could perhaps be triggered or advanced by V$\mathrm{V}$ contexts, in which mij is followed by a word with a vowel in the onset, so the nasal would be a linking element that helps avoid the hiatus created by two subsequent vowels (see Booij 1995:150-151). Therefore, phonetic context was also incorporated into the analysis.

\section{Results.}

\subsection{Overall Results per Period.}

For the first period (1660s-1670s), there are 2,047 tokens, 1,538 of which are with the nasal (mijn) and 509 are without (mij). For the second period (1770s-1780s), there are 4,901 tokens: 2,636 with the nasal, 1,455 without. Many instances occur as possessives (see also section 5.2): 1,082 in the 17 th century and 2,065 in the 18th. If one removes the possessive tokens, where mijn is almost categorical, the distribution in table 2 emerges.

\begin{tabular}{l|cc|cc|c} 
& \multicolumn{2}{|c|}{ +nasal } & \multicolumn{2}{c|}{-nasal } & N total \\
& $\boldsymbol{N}$ & $\mathbf{\%}$ & $\boldsymbol{N}$ & $\mathbf{\%}$ & \\
\hline $1660-1670 \mathrm{~s}$ & 454 & 47 & 511 & 53 & 965 \\
$1770 \mathrm{~s}-1780 \mathrm{~s}$ & 684 & 34 & 1,342 & 66 & 2,026
\end{tabular}

Table 2. Forms with (mijn) and without the nasal (mij), possessives excluded. 
Table 2 shows that among nonpossessives, the 17th-century data have an almost balanced distribution of forms with and without the nasal. The forms with the nasal are much more frequent than could be expected on the basis of published texts and metalinguistic discourse. The proportions change in the 18th century, when the forms lacking the nasal are in the majority with $66 \%$. This change is in line with the preference for forms without the nasal in published texts and metalinguistic discourse, though the frequency of forms with the nasal (mijn) can still be considered to be high, both in absolute and in relative terms.

\subsection{Internal Factors.}

For the $1660 \mathrm{~s}-1670 \mathrm{~s}$, the corpus has 2,047 tokens. Table 3 shows the proportion of forms with the nasal across the following grammatical functions: direct object, indirect object, prepositional phrase, reflexive, and possessive.

1660s-1670s: \% +nasal

\begin{tabular}{lrr}
\hline & $\boldsymbol{N}$ & $\mathbf{\%}$ \\
\cline { 2 - 3 } Direct object & 58 & 48 \\
Indirect object & 253 & 50 \\
Prepositional phrase & 174 & 59 \\
Reflexive & 26 & 54 \\
Possessive & 1,027 & 95 \\
\hline
\end{tabular}

Table 3. Proportion of forms with the nasal (mijn) across grammatical functions in period 1 .

The occurrence of forms with the nasal is around $50 \%$ among direct and indirect objects and reflexives. This rate is slightly higher in the case of prepositional phrases, which may be linked to the origin of the nasal forms in strings of the kind het is mijn boek 'it is my book' > het boek is van mijn lit. 'the book is of me', that is, 'the book is mine' (see section 3). Among possessives, forms with the nasal are dominant, though note that at 5\% the forms without the nasal still include 55 tokens. There used to be some discussion about the forms without the nasal (Koelmans 1966), but it is clear that they occur in 17th-century writing, albeit marginally when compared to mijn. Leaving the possessives aside, it does not seem justified to consider grammatical function to be a crucially 
intervening factor, and it is not taken into account in the following analyses. $^{2}$

On the assumption that the following phoneme may influence the choice of pronoun - in particular, that a following word with a vowel in the onset may trigger the use of mijn with the final nasal in order to avoid hiatus - all 17th-century tokens of mij and mijn were annotated for the right phonetic context with the exception of the possessive forms. The context could be either a consonant or a vowel. In addition, forms with initial $<\mathrm{h}>$ were kept apart, since prevocalic $/ \mathrm{h} /$ was and still is variable, that is, it can be deleted in many varieties of Dutch, especially in the southwest including the Zeeland area. Table 4 gives the results of this analysis.

\begin{tabular}{lrr}
\multicolumn{3}{c}{ 1660s-1670s: \% +nasal } \\
\hline \multirow{3}{*}{ Consonant } & $\boldsymbol{N}$ & $\boldsymbol{\%}$ \\
\cline { 2 - 3 } Vowel & 341 & 52 \\
$<\mathrm{h}>$ & 146 & 54 \\
\hline
\end{tabular}

Table 4. Proportion of forms with the nasal (mijn) in three phonetic contexts in period 1.

Table 4 shows that the following phoneme does not influence the choice of object pronoun. ${ }^{3}$ This is in line with earlier analysis based on the Letters as Loot Corpus, where it was also shown that phonetic factors tend to be of marginal importance and often do not explain patterns of variation in historical Dutch (Rutten \& van der Wal 2014:331-335, 378380). The phonetic context is not discussed any further.

\subsection{Regional and Social Variation.}

As the variable shows strong regional patterns today and has always been subject to a lot of indexical work, I first look at the main effects for

${ }^{2}$ A chi-square test comparing the results for Direct object, Indirect object, Prepositional phrase, and Reflexive gives a $X^{2}$ of $6.667(d f=3)$ and a $p$-value of .08 , which is not significant at $p<.05$.

${ }^{3} \mathrm{~A}$ chi-square test comparing the results for Consonant, Vowel, and $<\mathrm{h}>$ gives a $X^{2}$ of $0.71(d f=2)$ and a $p$-value of .70 , which is not significant at $p<.05$. 
region and social rank. Figure 1 shows the proportion of forms with the nasal across region and period. Black columns show data for the $1660 \mathrm{~s}-$ 1670 s, grey columns for the 1770s-1780s (ZEE=Zeeland, $\mathrm{SH}=$ South Holland, AMS=Amsterdam, $\mathrm{NH}=$ North Holland).

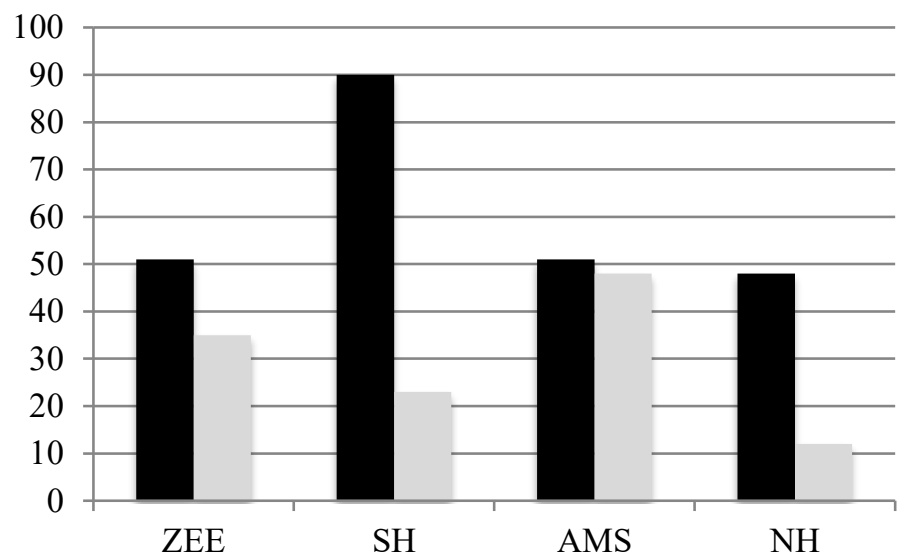

Figure 1. Proportion of forms with the nasal (mijn) across region and period.

Figure 1 shows that nasal forms make up ca. $50 \%$ of the tokens in the 17th century in Zeeland, Amsterdam, and North Holland, and in South Holland even $90 \%$. The proportion of nasal forms drops to $35 \%$ or less in the 18th century, except in Amsterdam. The high scores in 17th-century Zeeland and particularly in South Holland, where it can hardly be called a variable feature, and the low rates for nasal forms in 18th-century North Holland (12\%) suggest a rough north-south division also known from the present-day dialects, in which nasal forms are frequent in Zeeland, whereas North Holland is more variable (section 3). In the $1660 \mathrm{~s}-1670 \mathrm{~s}$, however, the center of the spread of nasal forms appears to be South Holland rather than Zeeland. South Holland is clearly leading the change, with its surrounding areas following suit. The diachronically more or less stable results for Amsterdam are discussed below.

Figure 2 presents the results across social rank for all regions taken together and for both periods. Letter writers from the lower, lowermiddle, and upper-middle ranks have ca. 50\% nasal forms in the 1660 s1670 s, which is in line with the overall results (see tables 2-4). Letter 
writers from the upper ranks use nasal forms $28 \%$ of the time in the first period, which drops to $18 \%$ in the $1770 \mathrm{~s}-1780 \mathrm{~s}$. The variable thus appears to have some social significance, which is even more pronounced in the second period, when the score for nasal forms among the lower ranks increases to $76 \%$. The two middle ranks (lower middle and upper middle) remain almost stable diachronically. In figure 2, black columns show data for the $1660 \mathrm{~s}-1670$ s, grey columns for the $1770 \mathrm{~s}-$ 1780 s.

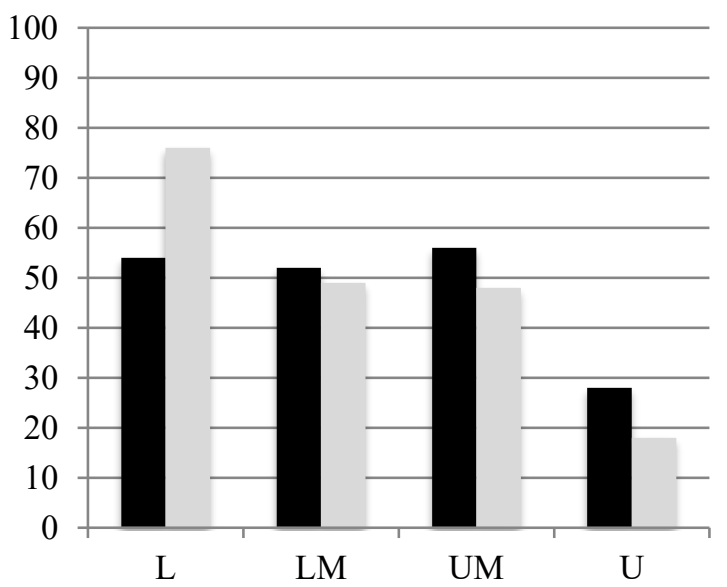

Figure 2. Proportion of forms with the nasal (mijn) across social rank and period ( $\mathrm{L}=$ lower, $\mathrm{LM}=$ lower middle, $\mathrm{UM}=$ upper middle, $\mathrm{U}=$ upper).

Figure 3 combines the diachronic results across social rank in the regions of Zeeland and South Holland. It shows that the scores for nasal forms in the lower-middle, upper-middle, and upper ranks in 17th-century Zeeland range from $40 \%$ to $79 \%$ (solid black line; there are no data for the lower ranks here), which drops across the ranks in the 18th century (dashed black line). This drop results in a social split with the upper ranks not producing any nasal forms, while the lower two ranks still use nasal forms between $60 \%$ and $70 \%$ of the time. A similar pattern can be seen in the neighboring area of South Holland, where all scores for the 1660s1670 s are above $64 \%$ (solid grey line). They are generally lower in the 1770s-1780s (dashed grey line), though still $93 \%$ in the lower ranks, and $50 \%$ in the lower-middle and upper-middle ranks. In the upper ranks, however, a sharp decrease to $2 \%$ can be witnessed. 


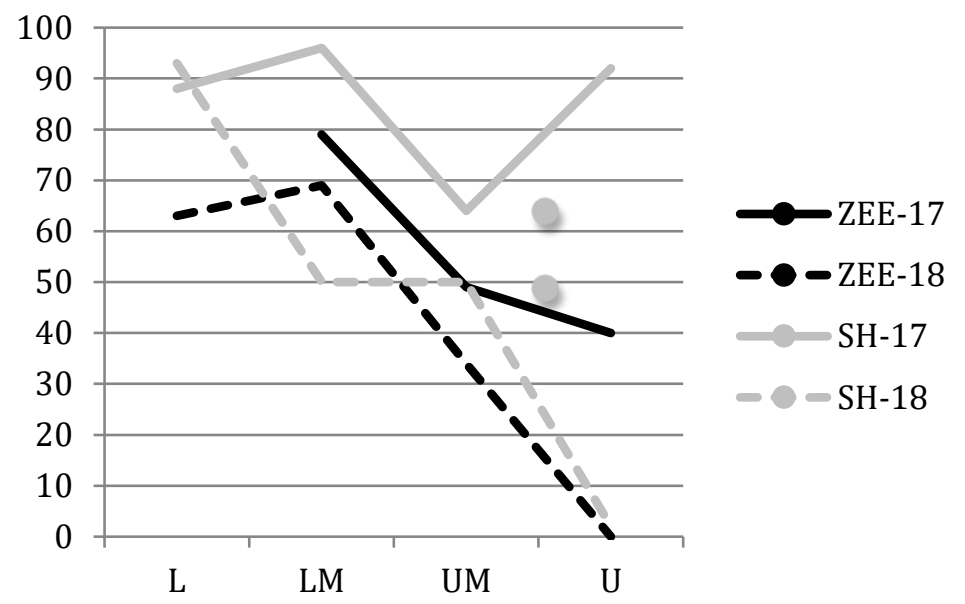

Figure 3. Proportion of forms with the nasal (mijn) across social rank and period in Zeeland (ZEE) and South Holland (SH).

Figure 4 shows the diachronic results across social rank in the two northernmost areas of Amsterdam and North Holland. The pattern in North Holland (grey lines) is similar to that in South Holland and Zeeland (figure 3 ), though scores are already lower in the 17th century. The North Holland middle ranks (LM and UM) show a decrease from over $50 \%$ in the 17 th century to less than $10 \%$ in the 18th century (there are no data for the upper ranks); the $100 \%$ score in the North Holland lower ranks in the $1770 \mathrm{~s}-1780 \mathrm{~s}$ is only based on 6 tokens. The proportions in North Holland are generally lower than in Zeeland and South Holland (figure 3), particularly in the 18th century, which confirms the somewhat loose northsouth division established above (figure 1).

The scores for Amsterdam (black lines in figure 4) seem to diverge from the general patterns established for Zeeland, South Holland, and North Holland. In the 1660s-1670s, the upper-middle ranks produce nasal forms $66 \%$ of the time, while in the other ranks the score is below $30 \%$, so Amsterdam is quite conservative with respect to the incoming nasal forms (solid black line). In the 1770s-1780s, however, the scores for the use of nasal forms are consistently higher, except in the uppermiddle ranks $(60 \%)$, where the scores were already quite high in the previous century (dashed black line). Note also that even the upper ranks show an increase from $6 \%$ to $32 \%$ in the use of nasal forms, as a result of 
which they move away from the extremely low scores shown by the upper ranks in all other regions in the 18th century. In other words, nasal forms appear to be on the way out in the other regions, with the upper ranks leading the change in the direction of conventional published language. In Amsterdam, however, nasal forms appear to be on the rise across the social ranks.

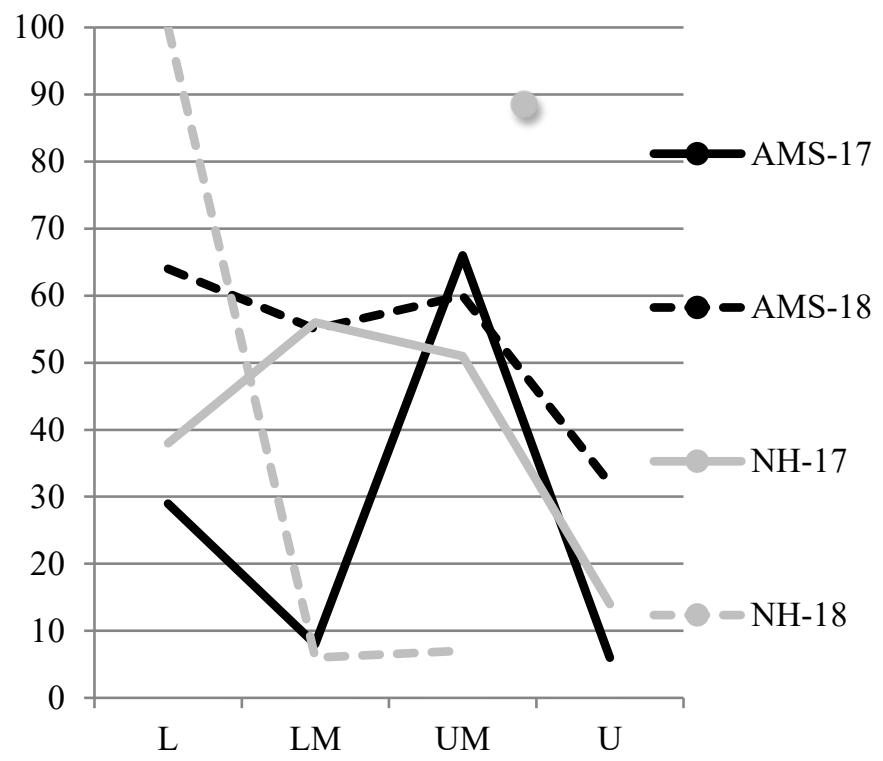

Figure 4. Proportion of forms with the nasal (mijn) across social rank and period in Amsterdam (AMS) and North Holland (NH).

Breaking down these Amsterdam numbers across gender is only feasible in some social groups. The score for women from the lowermiddle ranks increases from $8 \%$ nasal forms in the first period (based on 49 tokens) to $43 \%$ nasal forms in the second period (based on 47 tokens). Upper-middle ranked men from Amsterdam show an increase in the use of nasal forms from $47 \%$ to $57 \%$ (based on 92 and 267 tokens, respectively). Upper-middle ranked women use nasal forms $85 \%$ of the time in the first period (based on 94 tokens) and still $79 \%$ of the time in the second (based on 43 tokens). Men from the upper ranks, finally, show an increase in the use of nasal forms from 3\% (based on 33 tokens) to $27 \%$ (based on 189 tokens) in the $1770 \mathrm{~s}-1780 \mathrm{~s}$. In sum, there is a remarkable increase in the 
use of nasal forms in Amsterdam, contrary to the conventions of most published language and the metalinguistic tradition.

\subsection{Individual Variation.}

In section 2.2, it was argued that the level of individual variation with respect to negation in the 17th-century part of the Letters as Loot Corpus does not warrant an interpretation in terms of top-down standard norms. At the level of individual letter writers there was so much variation in the use of the two variants (bipartite and single negation) that almost any proportion seemed possible: Some authors opted for single negation all the time, others for bipartite negation, while 58 out of 84 , or $69 \%$ of the writers, showed variation. Thus, only 26 writers, or $31 \%$, were categorical users of either single or bipartite negation.

The results for mij and mijn show a different picture. Here, too, there are only two variants, with a supposed standard norm promoting one, namely, the form without the nasal. As in the case of the negation (section 2.2), only letter writers who produced five tokens or more were considered. Only the variable contexts of the direct and indirect object, the reflexive and prepositional phrases were taken into account since the possessive shows little variation. In the $1660 \mathrm{~s}-1670 \mathrm{~s}$, this approach leads to 56 letter writers from the regions of Zeeland, Amsterdam, and North Holland (in South Holland, nasal forms constitute a 90\% majority, so that the feature can hardly be called variable). A total of 33 letter writers, or $59 \%$, are categorical users of only nasal forms or of only forms without the nasal. In the $1770 \mathrm{~s}-1780 \mathrm{~s}$, the results from all four regions show 55 out 97 categorical users, or $57 \%$.

Another way to look at these data, also adopted in Rutten 2016c, is from the perspective of S-curve stages. The S-curve model of language change can be used to distinguish the following five stages in the process of adoption of the incoming form (Nevalainen \& Raumolin-Brunberg 2003:54-55):

(2) Proportion of the incoming form for each stage

Stage 1: incipient (below 15\%)

Stage 2: new and vigorous (between $15 \%$ and $35 \%$ )

Stage 3: mid-range (between $36 \%$ and $65 \%$ )

Stage 4: nearing completion (between $66 \%$ and $85 \%$ )

Stage 5: completed (over 85\%) 
Figure 5 plots the results for 84 individuals from the 1660 s -1670 s using single negation, as well as the results for 56 individuals from the 1660s-1670s using the incoming form mijn, and for 97 individuals from the 1770s-1780s using the incoming form mijn. The black columns representing the proportion of single negation show a gradual increase, with a small number of writers producing single negation less than $10 \%$ of the time, a large number of writers (32\%) producing single negation at least $85 \%$ of the time, and a considerable number of individuals being in stages 2,3 , and 4 . For the object pronoun mijn the situation is again very different. Both in the 1660s-1670s (light grey columns) and in the 1770s-1780s (dark grey columns), a large number of writers produce nasal forms $85 \%$ of the time or more. Likewise, a large number of individuals produce nasal forms less than $15 \%$ of the time, namely, $43 \%$ in both periods. The number of individuals in between is much lower than in the case of negation, suggesting the existence of a normative split in which individuals choose either the nasal form (mijn) or the form without the nasal (mij). Furthermore, this distribution does not change diachronically.

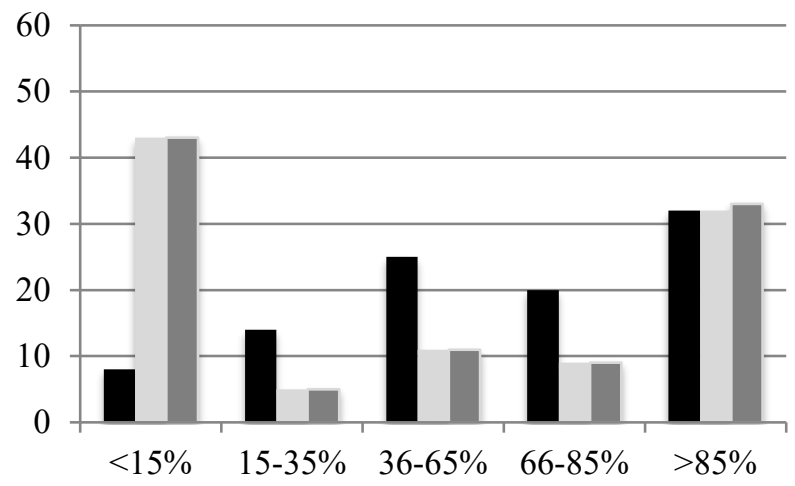

Figure 5. Proportion of letter writers with single negation in the 1660s1670 s, with nasal forms (mijn) in the 1660s-1670s, and with nasal forms in the 1770s-1780s.

It may be surprising that the numbers of categorical and almost categorical users of mij and mijn are so similar in the 17th and in the 18th century. After all, there is a general decrease in the use of nasal forms (table 2), and the variable also acquired some social significance (figure 
2). In particular, the similar distribution raises the question which individuals in Amsterdam in the 1770s-1780s still adopted the nasal forms. In view of the increasing social significance of the variable, this question is even more pressing in the case of individuals assigned to the upper-middle and upper ranks.

The social ranks in the Letters as Loot Corpus were determined on the basis of profession (see section 4 above). Female writers, who often lacked a profession, were assigned to the same ranks as their spouses. The 18th-century letter writers allocated to Amsterdam and to the upper and upper-middle ranks who produce (almost) only mijn are mostly merchants and captains, and their wives. There is also one auctioneer. These are professions requiring elaborate reading and writing skills, and these individuals therefore participated to a considerable extent in the written culture, which is an important predictor for various patterns of variation and change in historical Dutch (Rutten \& van der Wal 2014:401-404). More detailed information about the writers in the corpus is normally lacking, but one can inspect their letters for linguistic features that are remarkable in the light of earlier work. For example, it seems striking that three writers (F. Hogguer, Evert de Jonge, Maria Meester) still use the epistolary formula fris en gezond 'fresh and healthy' to describe someone's state of health. The use of this formula was largely restricted to the lower and lower-middle ranks (Rutten \& van der Wal 2014:144). Two of these individuals also use socially marked 1 st person verb forms (Rutten \& van der Wal 2014:328-330): ik sien 'I see' for $i k$ sie or $i k$ zie (F. Hogguer), and $i k$ wilt 'I want' for $i k$ wil (Maria Meester).

While these observations may suggest that the use of mijn co-occurs with other nonstandard or socially marked forms, a large group of writers (Andries Hansen, J.D. Piest, Gerharda Wirth, Carsten Smit, Jan Quiding, Wed. B.H. Joosten, Moses van Isaac Pretto Henriques) use mijn alongside markers of higher stylistic levels, such as originally French lexical items and present participles (Weerman et al. 2013:369; compare Frijhoff 2015). This shows not only that the (almost) categorical use of mijn constituted a viable option for these writers, but also, and more importantly, that they did not hesitate to select mijn as their norm in writing in spite of the previous and still ongoing selection of mij in published texts, metalinguistic discourse, as well as in the wider Dutch language community of the time. 


\section{Discussion and Outlook.}

From the perspective of traditional language histories, the form mij was selected for the standard early on, leading to hardly any instances of mijn in published texts from the 17th century onward, except in comedies and farces. However, the overall results of the present study (section 5.1) show that object forms with the nasal (mijn) were quite frequent in the $1660 \mathrm{~s}-1670 \mathrm{~s}(47 \%)$. In the $1770 \mathrm{~s}-1780 \mathrm{~s}$, the forms with the nasal were still quite frequent, though a decrease can be witnessed (33\%). Section 5.2 demonstrates that the internal factors discussed here, namely, syntactic function and phonetic context are not so important. Much more relevant are the results in sections 5.3 and 5.4. In the 17th century, the region of South Holland is the center of mijn-forms (90\%), while in the neighboring regions of Zeeland to the south, and Amsterdam and the rest of North Holland to the north, nasal forms are used ca. $50 \%$ of the time. This changes dramatically in the 18th century, when the use of the forms with the nasal decreases everywhere, except in Amsterdam. The general decrease in the regions under investigation leads to a social split in the distribution of forms: Upper-ranked individuals produce low proportions of forms with the nasal, particularly in Zeeland and South Holland. In the lower ranks, in contrast, nasal forms are more frequently adopted, also compared to the 17th century, so that there is in fact a diachronic increase. The low numbers of nasal forms in North Holland confirm the present-day dialectal distribution, according to which mijn is frequently used in the southern region of Zeeland, less so in the northern parts of Holland.

The city of Amsterdam is the exception to all of these patterns: There is an increase in the frequency of mijn, and this increase also occurs in letters from the upper-middle and upper-ranks. While one does see upper and upper-middle rank writers converge to the selected norm (mij) in other regions, there are still many upper and upper-middle rank writers in the 18th century who adopt mijn. Moreover, the use of mijn does not seem to be gradually decreasing, with mij taking over more and more contexts. Instead, the number of categorical users of mij and mijn is diachronically stable, and the only change is that categorical users of mijn are more often linked to Amsterdam than before. In other words, the social meanings attached to mij and mijn, visible in the near absence of mijn in published texts (van der Wal 2007), leads some writers to adopt $m i j$, while others keep selecting mijn. There is a normative split between 
users of mij and users of mijn, with only a small number of writers displaying variable use. This normative split does not become less strong diachronically.

Were these 18th-century Amsterdam writers merely putting their local variant to paper? Perhaps, although the present-day dialect situation shows that mijn is more frequent in Zeeland than in the Holland regions to the north of Zeeland. Note, however, that historical letter-writers in general did not aim to write down their local dialect (see, among others, Elspaß 2007:152, Rutten \& van der Wal 2014:72). On the contrary, what one finds in historical sources is usually a mixture of local and supralocal forms (Martineau 2013), and almost every writer was aware of supralocal conventions for writing, and for writing only, such as epistolary formulae and present participles in the case of Dutch. The question of the spoken form behind the written language is not the crucial issue in this context: The issue is that despite a strong supralocal tradition in favor of mij, backed up by published texts and metalinguistic discourse, some letterwriters still adopted, and kept adopting, mijn in writing.

This means that one is not witnessing a gradual change along an Scurve, similar to the change from bipartite to single negation. It is also not a simple case of top-down standardization with the long selected form mij gradually prevailing. What one has is a normative split with some writers converging to the selected form $m i j$ and others diverging from it by selecting mijn. Users of mijn can be found in the lower ranks generally and in any social rank in Amsterdam. There is, in other words, an extra layer of ongoing selection and standardization within the diaglossic repertoire. This is all the more significant since the phenomenon under discussion is a normalized feature with supposedly one and only one norm. Not only was actual language use quite variable when compared to this norm, but in addition language use showed conventionalization partly in line with the norm, and partly also diverging from it: A second norm was established, which was diametrically opposed to the supposed standard norm.

Elaborate sociolinguistic analyses of historical letter corpora have shown that the regional writing practices that are often associated with medieval times continue well into the 17th, 18th, and 19th centuries, and that the traditional idea of a common standard for writing does not apply to these postmedieval times (for example, Hendriks 1998, Elspaß 2005, Rutten \& van der Wal 2014). The present study has revealed that social 
and/or regional writing practices in 17th- and 18th-century Dutch may also show norm selection contradicting previous and well-established selection processes for the supposed standard. The form mijn is a variant that is simultaneously deselected by some language users and selected by others. Lack of detailed historical information about the writers in the corpus does not permit conjectures about individual motives for selecting mijn. It is furthermore impossible to reconstruct social networks on the basis of the letters in the corpus and the available metadata, so that research on other types of diffusion is difficult, if not unmanageable. At the level of the sociolinguistic situation in general, however, it is clear that the supposed standard was not a standard for all.

The rise of the standard language ideology in the 18th century led to the official codification of a Dutch standard in 1804 and 1805 (Rutten 2019), when official, state-sponsored regulations for spelling and grammar were published (Siegenbeek 1804, Weiland 1805). The form mij was codified without any reference to a possible alternative form mijn (Weiland 1805:103). Krogull (2018) presents the Going Dutch Corpus, a multigenre corpus designed specifically to determine the influence of these official regulations, while showing their success for a number of variables. The Going Dutch Corpus also comprises private letters, most of which are linked to the upper-middle and upper ranks in terms of the Letters as Loot Corpus. A quick search in the 19th-century part of the corpus, with private letters from the 1820-1840 period, reveals only 8 tokens of mijn (2\%) as opposed to 512 tokens of mij (98\%). This suggests that the secondary selection of mijn among upper and upper-middle rank individuals was halted under the influence of the official codification of Dutch. Whether mijn was maintained in other writings remains a question for future research.

\section{REFERENCES}

Auer, Peter. 2005. Europe's sociolinguistic unity, or: A typology of European dialect/standard-constellations. Perspectives on variation: Sociolinguistic, historical, comparative, ed. by Nicole Delbeque, Johan Van der Auwera, \& Dirk Geeraerts, 7-42. Berlin: De Gruyter.

Auer, Peter. 2011. Dialect vs. standard: A typology of scenarios in Europe. The languages and linguistics of Europe, ed. by Bernd Kortmann \& Johan van der Auwera, 485-500. Berlin: De Gruyter. 
Ayres-Bennett, Wendy. 2014. From l'usage to le bon usage and back. Norms and usage in seventeenth-century France. Rutten et al. 2014, 173-200.

Booij, Geert. 1995. The phonology of Dutch. Oxford: Clarendon.

Bree, Cor van. 1987. Historische grammatica van het Nederlands. Dordrecht: Foris Publications.

Bree, Cor van. 2012. Hun als subject in een grammaticaal en dialectologisch kader. Nederlandse Taalkunde 17. 229-249.

Dossena, Marina. 2012. The study of correspondence: Theoretical and methodological issues. Letter writing in Late Modern Europe, ed. by Marina Dossena \& Gabriella Del Lungo Camiciotti, 13-30. Amsterdam: John Benjamins.

Elspaß, Stephan. 2005. Sprachgeschichte von unten. Untersuchungen zum geschriebenen Alltagsdeutsch im 19. Jahrhundert. Tübingen: Niemeyer.

Elspaß, Stephan. 2007. "Everyday language" in emigrant letters and its implications for language historiography - the German case. Multilingua 26. 151-165.

Elspaß, Stephan. 2014a. Private letters as a source for an alternative history of Middle New High German. Letter writing and language change, ed. by Anita Auer, Daniel Schreier, \& Richard J. Watts, 35-52. Cambridge: Cambridge University Press.

Elspaß, Stephan. 2014b. Prescriptive norms and norms of usage in nineteenthcentury German. Rutten et al. 2014, 303-320.

Frijhoff, Willem. 2015. Multilingualism and the challenge of frenchification in the early modern Dutch Republic. Past, present and future of a language border. Germanic-Romance encounters in the Low Countries, ed. by Catharina Peersman, Gijsbert Rutten, \& Rik Vosters, 115-140. Berlin: De Gruyter.

Goeman, Ton, Marc van Oostendorp, Pieter van Reenen, Oele Koornwinder, Boudewijn van den Berg, \& Anke van Reenen. 2008. Morfologische atlas van de Nederlandse dialecten [Morphological atlas of the Dutch dialects], vol. II. Amsterdam: Amsterdam University Press.

Goss, Emily L., \& Robert B. Howell. 2006. Social and structural factors in the development of Dutch urban vernaculars in the early modern period.

Variation and reconstruction, ed. by Thomas Craven, 59-83. Amsterdam: John Benjamins.

Grondelaers, Stefan, \& Roeland van Hout. 2011. The standard language situation in the Low Countries: Top-down and bottom-up variations on a diaglossic theme. Journal of Germanic Linguistics 23. 199-243.

Halteren, Bronger van. 1906. Het pronomen in het Nederlandsch der zestiende eeuw. Wildervank: H.K. van Halteren.

Haugen, Einar. 1966. Dialect, language, nation. American Anthropologist 68. 922-935. 
Helten, Willem Lodewijk van. 1881. Vondel's taal. Een proeve van onderzoek naar de grammatica van het Nederlandsch der zeventiende eeuw. Vormleer. Rotterdam: Otto Petri.

Helten, Willem Lodewijk van. 1887. Middelnederlandsche spraakkunst. Groningen: Wolters.

Hendriks, Jennifer. 1998. Immigration and linguistic change: A socio-historical linguistic study of the effect of German and southern Dutch immigration on the development of the northern Dutch vernacular in 16th/17th century Holland. Madison, WI: University of Wisconsin dissertation.

Heule, Christiaen van. 1625. De Nederduytsche grammatica ofte spraec-konst. Ed. W.J.H. Caron. Groningen \& Jakarta (1953): Wolters.

Heule, Christiaen van. 1633. De Nederduytsche spraec-konst ofte taalbeschryvinghe. Ed. W.J.H. Caron. Groningen \& Jakarta (1953): Wolters.

Horst, Joop van der. 2008. Geschiedenis van de Nederlandse syntaxis. Louvain: Universitaire Pers Leuven.

Howell, Robert B. 2006. Immigration and koineisation: The formation of early modern Dutch urban vernaculars. Transactions of the Philological Society 104. 207-227.

Janssens, Guy, \& Ann Marynissen. 2005. Het Nederlands vroeger en nu. Louvain \& Voorburg: Acco.

Koelmans, L. 1996. My en sy als possessiva in de 16e en 17e eeuw. De Nieuwe Taalgids 59. 266.

Krogull, Andreas. 2018. Policy versus practice. Language variation and change in eighteenth- and nineteenth-century Dutch. Utrecht: LOT.

Langer, Nils. 2014. Standard German in the eighteenth century. Norms and use. Rutten et al. 2014, 277-302.

Lodge, Anthony. 2013. Codification and reallocation in seventeenth-century Paris. Taal \& Tongval 65. 57-72.

Martineau, France. 2013. Written documents: What they tell us about linguistic usage. Touching the past. Studies in the historical sociolinguistics of egodocuments, ed. by Marijke van der Wal \& Gijsbert Rutten, 129-147. Amsterdam: John Benjamins.

Nevalainen, Terttu. 2012. Variable focusing in English spelling between 1400 and 1600. Orthographies in Early Modern Europe, ed. by Susan Baddeley \& Anja Voeste, 127-165. Berlin: De Gruyter.

Nevalainen, Terttu, \& Helena Raumolin-Brunberg. 2003. Historical sociolinguistics. Language change in Tudor and Stuart England. London: Longman.

Nobels, Judith. 2013. (Extra) ordinary letters. A view from below on seventeenth-century Dutch. Utrecht: LOT.

Pickl, Simon. 2020. Factors of selection, standard universals, and the standardisation of German relativisers. Language Policy 19. 235-258. 
Poplack, Shana, Lidia-Gabriela Jarmasz, Nathalie Dion, \& Nicole Rosen. 2015. Searching for Standard French: The construction and mining of the Recueil historique des grammaires du français. Journal of Historical Sociolinguistics 1. 13-55.

Rutten, Gijsbert. 2016a. Historicizing diaglossia. Journal of Sociolinguistics 20. 6-30.

Rutten, Gijsbert. 2016b. The "Golden Age Myth": The construction of Dutch as a national language. Metalinguistic perspectives on Germanic languages. European case studies from past to present, ed. by Gijsbert Rutten \& Kristine Horner, 13-34. Oxford: Peter Lang.

Rutten, Gijsbert. 2016c. Diaglossia, individual variation and the limits of standardization: Evidence from Dutch. Current trends in historical sociolinguistics, ed. by Cinzia Russi, 194-218. Berlin: De Gruyter Open.

Rutten, Gijsbert. 2019. Language planning as nation building. Ideology, policy and implementation in the Netherlands, 1750-1850. Amsterdam: John Benjamins.

Rutten, Gijsbert, \& Marijke van der Wal. 2014. Letters as loot. A sociolinguistic approach to seventeenth- and eighteenth-century Dutch. Amsterdam: John Benjamins.

Rutten, Gijsbert, Rik Vosters, \& Wim Vandenbussche (eds.). 2014. Norms and usage in language history, 1600-1900. A sociolinguistic and comparative perspective. Amsterdam: John Benjamins.

Schönfeld, Moritz. 1970. Historische grammatica van het Nederlands. ed. by A. Van Loey. Zutphen: N.V. W. T. Thieme \& Cie.

Siegenbeek, Matthijs. 1804. Verhandeling over de Nederduitsche spelling. Amsterdam: Johannes Allart.

Sijs, Nicoline van der. 2004. Taal als mensenwerk. Het ontstaan van het ABN. The Hague: SDU.

Simons, Tanja. 2013. Ongekend achttiende-eeuws Nederlands. Taalvariatie in persoonlijke brieven. Utrecht: LOT.

Toorn, Maarten van den, Willy Pijnenburg, Arjan van Leuvensteijn, \& Joop van der Horst (eds.). 1997. Geschiedenis van de Nederlandse taal. Amsterdam: Amsterdam University Press.

Van Loey, Adolphe. 1980. Middelnederlandse spraakkunst. Deel I. Vormleer. Groningen: Wolters-Noordhoff.

Wal, Marijke van der. 1995. De moedertaal centraal. Standaardisatie-aspecten in de Nederlanden omstreeks 1650. The Hague: SDU.

Wal, Marijke van der. 2007. Eighteenth-century linguistic variation from the perspective of a Dutch diary and a collection of private letters. Germanic language histories "from below" (1700-2000), ed. by Stephan Elspaß, Nils Langer, Joachim Scharloth, \& Wim Vandenbussche, 83-98. Berlin: De Gruyter. 
Wal, Marijke van der, \& Cor van Bree. 2008. Geschiedenis van het Nederlands. Houten: Spectrum.

Wal, Marijke van der (programme leader), Gijsbert Rutten, Judith Nobels, \& Tanja Simons. 2015. Brieven als Buit [Letters as Loot corpus]. 2nd release. Leiden: Leiden University. Available at http://brievenalsbuit.inl.nl.

Weerman, Fred, Mike Olson, \& Robert A. Cloutier. 2013. Synchronic variation and loss of case. Formal and informal language in a Dutch corpus of 17thcentury Amsterdam texts. Diachronica 30. 353-381.

Weiland, Pieter. 1805. Nederduitsche spraakkunst. Amsterdam: Johannes Allart.

Centre for Linguistics (LUCL)

Leiden University

Reuvensplaats 3-4

Postbus 9515

NL-2300 RA Leiden

The Netherlands

[g.j.rutten@hum.leidenuniv.nl] 